\title{
Sufi Novels and Parables: A Significant Change in Doris Lessing's Writing
}

\author{
Shahram Kiaei \\ Faculty Member, Department of English, Islamic Azad University \\ Qom Branch, Qom, Iran \\ E-mail: shahramkiaei@yahoo.com
}

Received: November 21, 2011

Accepted: December 25, 2011 Published: January 1, 2012

doi:10.5539/ach.v4n1p41

URL: http://dx.doi.org/10.5539/ach.v4n1p41

\begin{abstract}
Doris Lessing, the Persian-born, African-raised and London-residing novelist enjoys a writing career which has spanned more than 50 years. Critics have labeled her as Marxist, feminist, Sufist and even psycho-analyst. It is my contention to prove that latent Sufi characteristics are inherent in her works, and this premise marks a difference between my study and other research on Lessing. To prove that even Lessing's early works contain Sufi characteristics, this paper looks at her early fictions which lend themselves to Sufistic interpretation. The theoretical framework used in this paper proves the manifestations of Sufism in her early works which involve different Sufistic concepts. The methodology appropriated entails tracing some of these concepts in these novels which are overtly Sufistic. I would also show how Lessing invites a Sufi reading of her novels and whether there are direct signs or changes in her choices of genre, mode, and style that suggest a new vision and a changed worldview and outlook. By revisiting her writing life to show that Sufism has always been present in her works, I depart from other critics and researchers who examine Lessing's works in more general terms. This departure is significant because the use of a non-western perspective actually enriches our understanding of Lessing who is mainly read from Eurocentric points of view.
\end{abstract}

Keywords: Sufism, Mysticism, Sufi teaching stories

\section{Introduction: A Revolutionary Transformation}

A significant change in Lessing's fictive technique in her Sufi novels is her use of teaching stories. A teaching story is an example of one of the many ways in which Sufi elements are transmitted, and it has been one of the main tools with which Idries Shah-the great Sufi master-has taught Sufism in the West. Lessing does not only directly employ Sufi teaching stories in the dedication to, for instance, The Four-Gated City, but she also attributes Sufi or Sufi-like anecdotes to her characters in this novel. She also structures many of her narratives in the form of tall tales and fables which offer enigmatic lessons that make sense in the Sufi context. These Sufistic narratives have the flavor of a fairy tale, "We all remember that time," begins, for example, in one of her novels entitled: The Memoirs of a Survivor; "You ask how the Canopean Agents seemed to us in the times of The Ice" (Lessing, 1974, p 5), begins the narrator in the opening of Lessing's other novel; The Making of the Representative for Planet 8.

In her preface to Shah's Seekers after Truth Lessing (2006: 634) writes, "It was they who developed, Sufis claim, the teaching story, an artifact created specifically for influencing the deepest and most hidden part of a human being-a part not accessible to any other approach". Lessing has been closely involved in the dissemination of these stories in the West which are taken from the East by way of giving public readings of Sufi stories and announcing the publication of collections by Shah, as well as by writing introductions and prefaces to collections of teaching stories such as Seekers after Truth and Learning How to Learn by Idries Shah, The Tale of the Four Dervishes by Amina Shah, and Kalila and Dimna by Ramsay Wood (1998). Lessing (2008: 635) adds in her preface to Shah's Seekers after Truth that "the teaching story is not to be considered as a parable, which the Sufis use, too; for the parable has a more limited aim, such as the inculcation of a moral, or ethics, or to transmit information". She actually views her attempts through these teaching stories to be observed as not a "hopeless task" but as an endeavor to open the mind's eye of the readers of such stories (cited in Ismaznizam, 2007: 55). I should conclude that to facilitate the readers' understanding of Lessing's teaching stories, this paper will first study the Sufi teaching story, which is a minute portion of the enigma that is Sufism, and which Shah uses as a teaching tool in transmitting 
Sufism to his readers and followers. Then, the potentiality of Lessing's characters as Sufis will be discussed. Finally, Lessing's selected novels which are Sufistic will be analyzed.

\section{The Sufi Teaching Story}

Sufi teaching stories were originally told orally and later written down for the main purpose of transmitting Sufi faith and practice to future generations. In the Middle East, where these stories are told and retold, they are not considered to be for children only; rather, they are said to contain several layers of meaning which render them suitable for people of all ages. Shah (1997: 88) likens the Sufi story to a peach:

A person may be emotionally stirred by the exterior as if the peach were lent to you. You can eat the peach and taste a further delight. You can throw away the stone-or crack it and find a delicious kernel within. This is the hidden depth.

It is in this manner that Shah invites his audience to receive the Sufi story. If one does not seek to uncover the kernel, one will have accomplished nothing more than looking at the peach or regarding the story as merely amusing and superficial, while others may internalize the tale and allow it to touch them. Like the Sufi teaching story therefore, Lessing attempts to incorporate multiple levels to invoke in the reader a new an original attitude of mind to the activity of reading, a strategy which she admires in Idries Shah.

In addition to the intentional layering in its content and structure, the Sufi teaching story also acquires embellishments of many more layers as it undergoes the natural transformation of travelling across time and space. Hence every story also becomes a new story in the retelling, acquiring new twists and mysteries depending on the idiosyncrasies of the particular storyteller and the context in which the story is being told. Lessing likens these longer tales to a ball of magic thread which

You unwind and unwind, going back and back, to long before the birth of Islam, and then still farther back, and you find yourself thousands of years away, and still the thread is unwinding, with no end in sight (Amina Shah 2009: xi).

One story leads the way to another and another, stories unfolding like Chinese boxes until the audience is lost in the maze. Finally no one cares about the very first king who had abandoned his kingdom in search of wisdom, and who had met four dervishes, each of whom had told a different story which had unfolded into many more stories. At that point of abandonment, the lesson is quietly learned, sometimes unbeknownst to the hearer. The most important purpose of enchanting the audience with this ball of magic thread, in addition to entertaining, is to blur the black-and-white distinctions between right and wrong, good and bad, cause and effect, villain and saint, guilty and innocent. Actions do not necessarily provoke the reactions one is conditioned to expect, the future is not always shaped by one's plans, and one's life and behavior are not as independently governed by the self as one would like to believe. Everything is infinitely interconnected, even if through bizarre and unexpected ties.

The Sufi tales translated and revised by Idries Shah frequently do not fit the above description of the longer Sufi stories. Rather, Shah eliminates many embellishments which characterize the original tales, thus considerably shortening them. He makes sure that the kernel of the stories is not completely obscured by centuries of accretions and tall tales. Thus, for instance, stories about Mulla Nasrudin, are frequently only a few sentences long in Shah's translations. Sometimes, Shah's renderings consist almost only of the moral itself, narrated to make its intent more accessible to the Western ear unaccustomed to search for Sufi wisdom amid layers of narrative. In her introduction to Amina Shah's collection Lessing explains the difference between the short and long stories:

One is precise and sharp, with instructions for students in a certain phase of study (as well as other dimensions, of course), and in a form appropriate for its existence for that phase; the second has the charm and the affability (Amina Shah 2009: xiii)

On the whole, whether condensed or not, Sufi teaching stories sufficiently disorient the reader's rational faculties so that a potential channel for discerning the story's wisdom can be established. Lessing does this in many of her later narratives, including The Memoirs of a Survivor, Briefing for a Descent into Hell, and Re: Colonised Planet 5, Shikasta. Perhaps in order to disorient her readers and to break mechanical thought processes, she does not provide clear markers in these novels. Assuming she emulates Sufi teaching stories, it has to be her hope that readers will relinquish their usual thought patterns and will allow the story to guide them to a fresh Space, time, and understanding. "Lessing writes to justify the ways of man to God, as Milton did to justify the ways of God to man.

The Sufi teaching story aims to shake the audience's existing worldview to such a point that one stops looking at the world through any single lens. The story allows for no fixed points of reference, daring its audience to transcend rational boundaries. It aims gently to remove blinders, to show a greater picture of reality. The expected logical result is eliminated by the change in the frame that shakes the participating party in the tale and the 
audience out of their habitual thought patterns. Ornstein (2006: 376) says:

These stories guide the reader along unfamiliar paths; Some contain a pattern of activity so that the reader can become familiarized with the unusual, and some are intended as 'shock'-a fresh stimulus to the mind to upset the normal paths of thought and consciousness.

The Sufi teaching story is meant to serve as a tool for growth and enlightenment. As Lessing (2010: xiv) writes in her introduction to Amina Shah's collection,

in whatever form it appears, whatever the kind of language, each tale has its place, its kind of pleasure; and each will appeal to the people who, for that time, are right for it, as it is right for them.

The Sufi teacher knows that the depth to which a story succeeds in touching its hearer and the degree to which the story is decoded depends upon the hearer's level of being. Hence at anyone telling, only the received portion of the tale can be considered the "real" story. The transmitter of Sufi stories is aware that for every single telling, there emerge as many "real" tales as the number of hearers in the audience. Knowing this, the Sufi teacher does not only expect multiple interpretations but intentionally creates teaching stories so as to evoke them. This is also what happens in Lessing's works. A Sufi reading of Lessing's fiction enhances, complements, and complicates other, non-Sufi analyses of her work.

A sample protagonist of Sufi teaching stories is the popular folk figure known as Nasreddin Hodja in Turkey, as Mulla Nasrudin in Iran, as Joha in North Africa, and by other names in other parts of the world. He is also well known in Greece and the former Soviet Union, where Muslims do not predominate. Stories and jokes about him have been made available to English speakers by many translators, including Shah. He is frequently referred to as simply "the Hodja" or "the Mulla," meaning "spiritual teacher." He is known and enjoyed by all in the Middle East as a spiritual teacher, a fool, a joker, a judge, and a trickster, as well as a victim; his witty stories are still told in the teahouses, coffeehouses, and homes throughout North Africa, the Middle East, and Central Asia. It is debatable whether the Hodja really lived or whether he is only legendary; however, according to popular lore, he lived in Central Anatolia in the thirteenth century during the reign of the Anatolian Seljuks, attended a Muslim theological school (medrese) in Sivrihisar, Turkey, worked as a prayer leader (imam) in the mosque, taught in a medrese, and was a government official. There is even a grave on a hilltop in Aksehir, Turkey, in Central Anatolia, to indicate that he did live. There is no question about the Hodja's popularity: he and his patient, long-eared best friend his donkey-are like family to every Turk.

Many westerners who are not familiar with the Nasreddin Hodja stories find them silly. When read with an awareness of the Sufi tradition, however, the silliness becomes part of the point. The humorous joke is the first level on which we are invited to respond. Knowing the stories of Nasreddin Hodja, we both smile and look beneath the surface. Lessing's direct quotes and simulation of them in her novels would suggest that she takes them seriously and gives them her full attention, in turn requiring our full attention and effort at, understanding her own stories that resemble Nasrudin's in spirit. As Dee Seligman (2008: 199) explains, "Sufi jokes mock the ultimate inadequacy of logic". For example, the Hodja demonstrates the interconnectedness in life when, while walking along a deserted street in the night, he sees a troop of horsemen coming toward him. Frightened out of his wits, he jumps over a wall and finds himself in a graveyard. The horsemen follow him and see the Hodja cowering with fear. "What are you doing there?" they ask him, and the Hodja replies, "It is more complicated than you assume! You see, $I$ am here because of you; and you, you are here because of me (51)."

On the surface, this is a great joke and its message is obvious. We can take the Hodja at his word. On further examination, the story also illustrates the inevitable interconnectedness of human life-that one can do nothing without affecting others and that one's actions open up infinite new possibilities and have unlimited consequences and repercussions like rings in a pond. Still deeper is embedded the fundamental understanding between the Sufi master and the disciple: the former needs the latter as much as the disciple needs the master to move up the evolutionary Sufi ladder. They are interdependent. Yet another layer might be that until the disciple appears, the master is not yet a teacher; and until one recognizes the teacher, one does not know what one is seeking, or what one is meant to do. The story sets up a simple, humorous circumstance under which the master and disciple can recognize, then in turn identify, one another: $I$ am here because of you, and you are here because of $m e$ ! Perhaps a deeper layer would disclose the disbelieving novice on the path who fears, rather than loves, God and yet who cannot escape God's presence on a deserted street or in a graveyard, in life or after death.

This Paper refers both to the tales that Lessing quotes from the wealth of Sufi literature and to the tales that she herself has created. The latter are of two kinds: shorter anecdotes within a novel and an entire novel acting as a teaching tale from beginning to end. Hardin (2008: 319) writes, "One will discover that the Lessing story contains the same components as the Sufi story for in both moments of wakeful insights" are the focus. In her article, 
"Humor and Survival," Stitzel (2009: 61) remarks that the Nasrudin jokes provide one form of relief from the usual sober context of Lessing's novels. Stitzel (ibid) acknowledges the jokes' methodology of breaking conditioned thought processes and actions. This Paper studies some of the salient teaching stories by Lessing including: The Four-Gated City (1969); The Diary of a Good Neighbour (2010) and The Marriages between Zones Three, Four, and Five (1980). I believe that these novels communicate the Sufi message through the direct use of quotations from Sufi literature as well as through the use of characters as constructs, role models, and potential Sufis. They by no means exhaust the ways in which Sufism has permeated Lessing's works. The analyses in this Paper may also be applied to other novels by Lessing where she emulates Sufi teaching stories.

\section{Lessing's Characters as Potential Sufis}

Regardless of whether Lessing strictly follows and advocates Sufism, she manifests a strong sense of duty to teach and to demonstrate the development of consciousness through daily struggle and much suffering. To this end, she subordinates her characters to her message in her teaching stories. She appears to be only secondarily interested in a protagonist as a well rounded person and as a character in her own right. For instance, we get to know Anna Wulf in choppy, kaleidoscopic segments and Martha Quest, named after her occupation, the quest for herself, in the fragmented pieces of a mosaic. With the introduction of the narrator in The Memoirs of a Survivor, Lessing's characters carry fewer mimetic responsibilities and function more on synthetic and thematic levels to serve as vehicles in Lessing's teaching stories. At the same time the readers' full acceptance of their mimetic reality always remains crucial for understanding Lessing's message.

Lessing's development of characters who are under varying degrees of Sufi influence can be understood better along the lines that James Phelan (2008: 11) draws among the three dimensions of character namely, the mimetic, synthetic, and thematic. For Phelan, the mimetic dimension reminds us that characters are images of possible, growing people with traits such as beauty, maleness or shyness. The way and degree to which these traits coalesce to create a plausible person results in the mimetic function. The synthetic dimension is the artificially constructed component that remains covert in realistic texts, although all characters are fundamentally synthetic constructs. As such, they serve as devices that behave as protagonist, antagonist, or minor character who carry out various roles to further the plot. Whenever characters perform their plot functions, they are carrying out their synthetic function. Usually, the more we become aware of the synthetic component, the more the reality of a character as mimetic diminishes, and vice versa. Finally, the thematic dimension of characters refers to their ideational component and representativeness of a class, such as bigots, revolutionaries, or individualists. Phelan (2008: 11) argues that there is no fixed relationship among the components of character that all narratives share. Instead, he claims that progression of any narrative establishes the particular relation among components for that text.

Using these terms helps to identify the different uses Lessing makes of her characters to communicate Sufi ideas. For example in The Making of Representative for Planet 8 when we identify envoys such as Johor and Doeg as Sufi masters and disciples on the Sufi Path we are actually considering them to be more than literary tools used by Lessing. In this light, they become not only synthetic characters designed to communicate Lessing's ideas, nor only thematic characters designed to embody those ideas, but also mimetic models designed to invite us to experience vicariously some of what it means to live and suffer the lives of actual Sufi mystics: Johor is a plausible Sufi master; Doeg is a believable disciple on the Sufi Path. Taking for granted that Lessing wants us to accept the reality of another world, her characters must be understood not just as rhetorical devices to be "read past" as we seek her ideas but also as plausible characters whose ways of being are crucial for our understanding of Lessing's ideas. And at the same time, as true Sufi mystics, their individual mimetic existences and egos do not matter in themselves but are significant only insofar as they contribute to the greater evolution of all human life. paradoxically, then, our awareness of the relative insignificance of their individual identities depends precisely upon our recognition of those identities.

Moving further into the realm of space fiction in the Canopus series, Lessing reduces even more of the mimetic dimension of her protagonists. They mainly serve as tools to demonstrate an allegory in which Lessing articulates her view of humankind and history. Therefore it becomes more difficult for us to identify with the characters, for they are only more important because of the ideas that they represent. Yet their mimetic dimensions and functions provide the key to Lessing's message to her readers. In the life, suffering, and death of characters such as Doeg or Al-Ith, rather than in their raison d'etre-the reason of existence or being-as constructs, can the reader find exemplary models worth imitating.

In the preface to Shikasta (2005: ix) Lessing writes by way of explanation,

It is by now commonplace to say that novelists every-where are breaking the bonds of the realistic novel 
because what we all see around us becomes daily wilder, more fantastic, incredible and . . . fact can be counted on to match our wildest inventions.

Having exhausted the possibilities in the existing, visible world, Lessing creatively appropriates the world of fantasy in which she can show what is possible. She (1980: xiii) writes in the preface to The Sirian Experiments, "It has been said that everything man is capable of imagining has its counterpart somewhere else, in a different level of reality". Therefore, space fiction serves Lessing as the appropriate genre through which she can express her insights into human consciousness. It illustrates Lessing's conviction that human beings must learn to expand their minds to new ways of seeing, thinking, and being if they wish to survive.

In The Making of Representative for Planet 8, written as a tall tale, characters cannot even keep the same name for long but change their names as their nature and roles on the planet change. For instance, anyone involved in building is named "Masson" for the stretch of time that he remains a builder. The effect of the subordination of characters to Lessing's teaching is that we are hardly interested in them as heroes and heroines but rather in their allegorical role in the planet's evolution. Likewise, Lessing is interested not directly in the plight of individual human beings but in their roles in the evolution of the whole of the human race within the expanse of the universe. In her preface to The Sirian Experiments she (2008: ix) adds,

I would so like it if reviewers and readers could see this series, Canopus in Argos: Archives, as a framework that enables me to tell (I hope) a beguiling tale or two; to put questions, both to myself and to others; to explore ideas and sociological possibility.

In her preface to Shikasta Lessing (2005: ix) shares her

exhilaration that comes from being set free into a larger scope, with more capacious possibilities and themes ... It was clear I had made-or found-a new world for myself, a realm where the petty fates of planets, let alone individuals, are only aspects of cosmic evolution expressed in the rivalries and interactions of great galactic Empires: Canopus, Sirius.

Lessing's concerns do not stop at the level of individuals on earth but go beyond the visible world; she wants her protagonists to make efforts on a cosmic level where they will contribute to a universal growth and the survival of humanity, and her overall message supports this common cause. It is possible here to interpret that Lessing was originally attracted to the Sufi concept of evolution as a change away from the political sphere. The emphasis which the theory placed on growth consolidated Lessing's belief in the inherent potential of mankind to achieve a degree of personal development. To conclude my argument, I refer to the quote which Lessing has directly taken from Idries shah in The Four-Gated City (2009: 492) concerning the Sufi concept of evolution;

Sufis believe that, expressed in one way, humanity is evolving towards a certain destiny. We are all taking part in that evolution. Organs come into being as a result of a need for specific organs. The human being's organism is producing a new complex of organs in response to such a need. In this age of the transcending of time and space, the complex of organs is concerned with the transcending of time and space. What ordinary people regard as sporadic and occasional bursts of telepathic and prophetic power are seen by the Sufi as nothing less than the first stirrings of these same organs.

The Sufis, therefore, argue that mankind is currently evolving towards a new form of existence. The difference between all evolution in past history and mankind's present need for development, is that humanity has recently been offered the possibility of taking a conscious part in this process. The Sufis feel that the future of mankind depends on a realization that an opportunity exists to actively participate in this organic development. Lessing's adherence to this central tenet of Sufism helps to explain her attitude towards human beings in their roles in the evolution of the whole of the human race within the expanse of the universe.

\section{Conclusion: Lessing's Teachings}

In sum, It can be said that Sufi ideas clearly afford Lessing-the-seeker the opportunity to investigate the possibilities of tapping other spheres of consciousness that in turn force Lessing-the-novelist to experiment with new fictive techniques in order to convey her messages better. Among Lessing's messages is the fact that not all beings live on the same level of consciousness, but that all beings are given equal opportunity to rise above the level at which they were born. In The Four-Gated City the opening teaching story encapsulates Lessing's message in a nutshell: beings who think they can survive compartmentalizing their lives or isolating parts of themselves in neatly divided quarters are fools.

Moreover, the lives of the protagonists in Lessing's fictions require a change in fictive technique. Characters seem to have made demands on Lessing's choices of genre, mode, and style that can enable them to exercise the fullest 
freedom within their fictional worlds. Consequently, they require Lessing to provide for them a revised vision, and a new cosmology to match that vision, for them to inhabit.

The characters in Lessing's novels, especially in The Four-Gated City, are most important in the roles they play as envoys and models for us, and less so as whole individuals with completely mimetic lives. Ultimately, what matters, Lessing impresses upon us, is their contribution to the greater plan. Saul Green, Anna Wulf's "other" self, in The Four-Gated City, describes his contribution to this common cause:

There are a few of us in the world; we rely on each other even though we don't know each other all the time. We're a team, we're the ones who haven't given in, who'll go on fighting. I tell you, Anna, sometimes I pick up a book and I say: Well so you've written it first, have you? Good for you. OK then I won't have to write it (Lessing, The Four-Gated City, 2009, p 642).

In keeping with Sufi teachings, Lessing stresses the importance of commitment to self-remembering so that one may live by the guidance of one's mind, body, and heart, and make discoveries about the self who perpetually approaches that elusive shadow of the Other one is to know. This idea of "remembering" is a central theme in Sufism and in many of Lessing's novels. Like a Sufi master, Lessing impresses upon us our responsibility for the small part we are privileged to play in the greater evolution of humanity and the universe, by fulfilling our individual destinies.

\section{References}

Gurdjieff, G. I. (1975). Views from the real world. New York: Dutton.

Gurdjieff, G. I. (2010). All and everything: Beelzebub's tales to his grandson. Volume 3. New York: Dutton.

Hardin, N. S. (2003). The Sufi teaching story and Doris Lessing. Twentieth-Century Literature, 23 (3), 314-26

Hardin, N. S. (2008). Doris Lessing and the Sufi way. Contemporary Literature, 14 (4), 565-81.

Hollows, J. (2000). Feminism, femininity and popular culture. Manchester: Manchester University Press.

Lessing, D. (1979). Re: Colonised planet 5, Shikasta. New York: Knopf.

Lessing, D. (1980). The marriages between zones three, four, and five. New York: Vintage.

Lessing, D. (1994). Under my skin. New York: Harper.

Lessing, D. (2005). Shikasta. New York: Knopf.

Lessing, D. (2005). The story of general Dann and Mara's daughter. New York: Oubleday.

Lessing, D. (2007). The cleft. London: Greenwood Press.

Lessing, D. (2008). Alfred and Emily. London: Octagon.

Lessing, D. (2008). On not winning the nobel prize. New York: Oak Tree Fine Press.

Lessing, D. (2008). The Sirian experiments. New York: Popular Library.

Lessing, D. (2009). The four-gated city. New York: Knopf.

Lessing, D. (2010). The making of the representative for planet 8. New York: Knopf.

Lessing, D. (2010). The sentimental agents in the Volyen empire. New York: Knopf.

Ornstein, R. E. (2006). The psychology of consciousness. New York: Harcourt Brace Jovanovich Inc.

Phelan, J. (2008). Reading people, reading plots: Character, progression, and the interpretation of narrative. Chicago: U of Chicago P.

Rubenstein, R. (1983). The marriages between zones three, four, and five. Doris Lessing's alchemical allegory. Extrapolation, 24 (3), 201-15.

Seligman, D. (2008). Doris Lessing: An annotated bibliography of criticism. London: Greenwood Press.

Shabistari, S. M. (1974). The secret garden. Translated by Johnson Pasha. London: Octagon.

Shah, A. (2009). The tale of the four dervishes and other Sufi tales. San Francisco: Harper.

Shah, I. (1997). The exploits of the incomparable Mulla Nasrudin. New York: Dutton.

Shah, I. (2006). Seekers after truth. London: Octagon.

Shah, I. (revised.2006). The Sufis. New York: Doubleday.

Stitzel, J. (2009). Reading Doris Lessing. College English, (3) Vol 2. pp. 498-505. 
Vlastos, K. (2007). Slaughterhouse five; or, the children's crusade: A duty dance with death. New York: Dell.

Walder, D. (2010). Literature in the modern world: Critical essays and documents (pp. 333-341). Oxford: Oxford University Press. 